\title{
Involvement of TLR7 and TLR8 in conceptus development and establishment of pregnancy in sheep
}

\author{
Irene Ruiz-González, Megan Minten, Xiaoqiu Wang, Kathrin A Dunlap and Fuller W Bazer \\ Department of Animal Science, Texas A\&M University, Room 442 Kleberg, College Station, Texas 77843-2471, USA \\ Correspondence should be addressed to FW Bazer; Email: fbazer@cvm.tamu.edu
}

\begin{abstract}
Toll-like receptors (TLRs) belong to the innate immune system and regulate inflammatory events that affect mammalian reproduction. In Study 1, we demonstrated that abundance of ovine TLR1-TLR9 mRNAs in the uterus differs due to reproductive status (TLR2, TLR3, $T L R 7$, and TLR8) and the day of the estrous cycle and pregnancy (TLR1-TLR3, TLR5-TLR7, and TLR9). Expression of TLR7 and TLR8 proteins was localized primarily to uterine epithelia and stroma and regulated in a temporal manner. In Study 2, we determined that ovine conceptuses express TLRT and TLRB on all days studied and that expression of the envelope protein of ovine endogenous retrovirus (enJSRV-Env) declined in conceptus trophectoderm from Day 13 to Day 16 of pregnancy. In Study 3, loss-of-function experiments were conducted in vivo using morpholino antisense oligonucleotides (MAOs) injected into the uterine lumen to block synthesis of TLR7 and TLR8 proteins, individually and jointly. Conceptuses were recovered on Day 16 to assess their morphology. MAO-treated conceptuses were developmentally retarded, produced less interferon tau (IFNT), and had fewer binucleate cells (BNCs) compared with MAO-Controls. Moreover, expression of enJSRV-Env mRNA in MAO-TLR7 conceptuses was greater than that for MAO-Control and MAO-TLR8 conceptuses, but similar to MAO-TLRT/TLR8 conceptuses. Results of this study indicated differences in TLR1-TLR9 expression due to reproductive status and the day of the estrous cycle and pregnancy. TLR7 and TLR8 also influence development, enJSRV-Env abundance, secretion of IFNT, and formation of BNCs by conceptuses. These findings corroborate our hypothesis that TLR7 and TLR8 mediate pathways whereby enJSRV-Env regulates key peri-implantation events in conceptus development and differentiated functions of trophectoderm cells.

Reproduction (2015) 149 305-316
\end{abstract}

\section{Introduction}

The intrauterine immune system in mammals must be finely regulated during pregnancy to allow for development of the semi-allogeneic conceptus (embryo and the associated extra-embryonic membranes) and, at the same time, protect against invading pathogens. Progesterone, the hormone of pregnancy (Spencer et al. 2004), has been reported to down-regulate the immune system at the maternal-conceptus interface to establish an antiinflammatory milieu that favors continuation of pregnancy (Hansen 1998). However, large numbers of immune cells are recruited into the endometrium during the estrous cycle and pregnancy to participate in events of uterine remodeling, maternal tolerance, vascularization, and placentation (Segerson et al. 1991, Leonard et al. 2006, Laskarin et al. 2007, Gomez-Lopez et al. 2010, Nagamatsu \& Schust 2010, Mansouri-Attia et al. 2012). Lacking this influx of immune cells or their aberrant function leads to infertility and pregnancy loss (Greenwood et al. 2000, Plaks et al. 2008, Guerin et al. 2009, Jabbour et al. 2009, Erlebacher 2013). Therefore, it is unlikely that the maternal immune system is suppressed during pregnancy. Rather it is appropriately tuned to be permissive to the presence of the conceptus and collaborate with cytokines from the conceptus to ensure a successful outcome of pregnancy.

Pattern recognition receptors (PRRs) are innate immune cell receptors involved in the initiation of immunological responses to highly conserved pathogenassociated molecular patterns (PAMPs) (Janeway \& Medzhitov 2002). Among the families within PRRs are the Toll-like receptors (TLRs), which have been most studied and considered to be the first line of defense against pathogens (Akira \& Hemmi 2003).

Mammalian TLRs are transmembrane type I proteins with a leucine-rich repeat ectodomain (LRR) for ligand recognition, a single transmembrane domain which differs among TLRs, and a TIR domain for signal transduction (Akira et al. 2001). Of the 13 TLRs identified in mammals (Hansen et al. 2011, Jungi et al. 2011), ten are known to be expressed in domestic ruminants (Menzies \& Ingham 2006, Chang et al. 2009), which display high homology with their human counterparts (Nalubamba et al. 2007, Tirumurugaan et al. 2010). Besides TLR10, for which no function has been established, TLR ligand specificity 
depends on cellular location with some being expressed on the cell surface (TLR1, TLR2, TLR4, TLR5, and TLR6) for recognition of bacterial and fungal compounds, and others being localized to the endosomal compartment (TLR3, TLR7, TLR8, and TLR9), where they mainly bind nucleic acids from viral pathogens (Kawai \& Akira 2009, Kumar et al. 2009).

The finding of TLRs in non-typical immune cells such as the epithelia (Young et al. 2004, Turner et al. 2012) has implicated these receptors in many physiological events besides pathogen recognition ( $\mathrm{Li}$ et al. 2010). Available evidence indicates potential involvement of TLRs in mammalian reproduction, which requires an appropriate inflammatory balance among steroid hormones, cytokines, and prostaglandins to assure cyclical uterine remodeling for establishment and maintenance of pregnancy (King \& Critchley 2010, Ott \& Gifford 2010, Dorniak et al. 2011). TLR-mediated cell signaling cascades involve the cytokine inductor nuclear factor kappa $\beta$ (NFKB) and interferon regulatory factors (IRFs) to induce type I interferons (IFNs) (Kumar et al. 2009). Both of these pathways are actively regulated in the female reproductive tract, and their deregulation leads to infertility and disease (Spencer et al. 1998, King et al. 2001, Fleming et al. 2009, Ross et al. 2010, Hadfield et al. 2011, Maybin et al. 2011).

Gestation has been considered a Th2 or antiinflammatory environment, achieved through suppression of the NFKB pathway and increased abundance of interleukin 10 (IL10), IL4, or IL5 (Piccinni et al. 2001, Hadfield et al. 2011). However, Th1 (pro-inflammatory) molecules such as tumor necrosis factor alpha (TNFA) and IFNgamma (IFNG) are also necessary for uterine receptivity, implantation, and placental development in some species (Ashkar \& Croy 2001, Hess et al. 2007, Paulesu et al. 2010, Warning et al. 2011, Granot et al. 2012). Moreover, type I IFNs play an indisputable role during early pregnancy in ruminants, as the conceptus signals its presence to the mother by producing high levels of interferon tau (IFNT). IFNT abrogates development of the luteolytic mechanism and activates IFNT-regulated pathways in the uterus, which influence gene expression within the maternal environment leading to production of histotroph (Spencer \& Bazer 2004, Gray et al. 2006, Bazer et al. 2008).

The abundance of TLRs in immune cells depends on the dominant cytokine milieu (O'Mahony et al. 2008) and, therefore, it seems reasonable that strong conceptus-maternal signaling during the course of pregnancy influences expression of TLRs in the female reproductive tract and conceptus. Indeed, human endometrial epithelia and stromal cells express TLR1-TLR10, with higher levels during the progesterone-dominated secretory phase of the menstrual cycle (Jorgenson et al. 2005, Aflatoonian et al. 2007, Hirata et al. 2007). Moreover, a microarray analysis found significant up-regulation of genes involved in the TLR pathway in the mouse uterus during the implantation period (Pan et al. 2006). In addition, TLR expression in the placenta is regulated in a temporal and spatial manner (Koga \& Mor 2010) and the trophoblast modulates the maternal environment through TLR-mediated pathways (Abrahams et al. 2004, 2005). Despite evidence for their involvement in uterine biology of humans and mice, there is a lack of information regarding the role of TLR-mediated pathways in ruminants. Reports on expression of TLR1-TLR10 in bovine endometria describe differences in expression between epithelial and stromal cells (Herath et al. 2006, Davies et al. 2008) and their abundance in uterine endometrium of goats (Tirumurugaan et al. 2010).

Therefore, this study examined temporal and cellspecific patterns of expression of TLRs in uteri of cyclic and pregnant ewes during the period of pregnancy recognition signaling by IFNT. In addition, in vivo loss of translation of TLR7 and TLR8 mRNAs in the trophectoderm was achieved during this same period of pregnancy using morpholino antisense oligonucleotides (MAOs) with the aim of assessing the role of both TLR7 and TLR8 in conceptus development, production of IFNT, and formation of binucleate cells (BNCs). Finally, levels of mRNA coding for the envelope protein of ovine endogenous retrovirus (enJSRV-Env) were analyzed in MAO-treated conceptuses, as these viral particles influence implantation in the sheep (Dunlap et al. 2005, 2006a, Black et al. 2010). The overall aim of this study was to advance understanding of the role of TLRs in key events that regulate maternal recognition of pregnancy and implantation in the ewe.

\section{Material and methods}

\section{Experimental design}

Mature Rambouillet ewes (Ovis aries) were observed daily for estrus (Day 0 is the day of onset of estrus) in the presence of vasectomized rams and assigned to experiments after exhibiting at least two estrous cycles of normal duration (16-18 days). All experimental and surgical procedures were performed in compliance with the Guide for the Care and Use of Agriculture Animals in Research and Teaching and approved by the Institutional Animal Care and Use Committee of Texas A\&M University.

\section{Study 1}

At onset of estrus and on Day 1, ewes were mated to either a vasectomized ram or an intact ram of proven fertility. Ewes were then assigned randomly to be ovariectomized-hysterectomized on Day 10,12, 14, or 16 of the estrous cycle or Day 10, 12, 14, 16,18 , or 20 of pregnancy ( $n=4-5$ ewes/day and status) as described previously (Spencer et al. 1999). Pregnancy was confirmed by the presence of a morphologically normal conceptus and a functional corpus luteum $(\mathrm{CL})$. 
At hysterectomy, sections $(\sim 0.5 \mathrm{~cm})$ from the mid-portion of each uterine horn ipsilateral to the $\mathrm{CL}$ were fixed with fresh $4 \%$ paraformaldehyde in PBS ( $\mathrm{pH}$ 7.2). After $24 \mathrm{~h}$, fixed tissues were changed to $70 \%$ ethanol $(\mathrm{v} / \mathrm{v})$ for $24 \mathrm{~h}$, dehydrated through a graded series of alcohol to xylene, and then embedded in Paraplast-Plus (Oxford Labware, St Louis, MO, USA). The remaining endometrium of the ipsilateral uterine horn was physically dissected from the myometrium, frozen in liquid nitrogen, and stored at $-80^{\circ} \mathrm{C}$ for subsequent RNA extraction processes.

\section{Study 2}

Ewes were mated at the onset of estrus (Day 0) and on Day 1 to fertile rams. At mating, ewes were assigned randomly in groups for recovery of the conceptus on Day 13, 14, 15, or 16 of pregnancy ( $n=4 / 5$ conceptuses/day) by flushing the uterus with $10 \mathrm{mM}$ Tris buffer. Conceptuses were snap frozen in liquid nitrogen and stored at $-80{ }^{\circ} \mathrm{C}$ for RNA extraction.

\section{Study 3}

Morpholino oligonucleotides designed and synthesized by Gene Tools (Philomath, OR, USA) were directed against mRNAs coding for TLR7 (MAO-TLR7; GAAACTGTCTCTTCAATGTCCACAT) and for TLR8 (MAO-TLR8; TCAGAAGCAAAAAGTGAAGGGTCAT). The MAO-Control had the sequence CCTCTTACCTCAGTTACAATTTATA. All morpholinos were synthesized with a $3^{\prime}$-lissamine modification to detect and confirm uptake of each MAO by the trophectoderm, while confirming absence of uptake by uterine epithelia (see Wang et al. 2014).

Rambouillet ewes were mated on Days 0 and 1 to rams of proven fertility. On Day 8 post-mating, ewes were subjected to a mid-ventral laparotomy as described previously (Dunlap et al. 2006a). The base of the uterine horn ipsilateral to the CL was double ligated to prevent migration and growth of the conceptus into the contralateral uterine horn. This procedure does not affect development or implantation of ovine conceptuses (Dunlap et al. 2006a). MAO-TLR7, MAO-TLR8, and MAO-Control were complexed with Gene Tools Endo-Porter delivery reagent $(50 \mu \mathrm{l})$ and diluted to a final volume of $1 \mathrm{ml}$ with OPTI-MEM (Invitrogen). Double knockdown of translation of both MAO-TLR7 and MAO-TLR8 (hereafter noted as MAO-TLR7/TLR8) was prepared by mixing equal volumes of MAO-TLR7 and MAO-TLR8. The respective MAOs were introduced into the uterine lumen ( $n=6 / 8$ ewes/ treatment) via a catheter inserted just below the tubo-uterine junction. After the MAOs were discharged into the uterine lumen, the uterine horn was gently massaged to distribute the morpholinos throughout the uterine lumen. The outside of the uterus was then rinsed with saline containing $10 \%$ glycerol to reduce adhesions and then returned to the abdominal cavity.

Morpholino-treated ewes were hysterectomized on Day 16. The uterine horn injected with a morpholino was flushed with $10 \mathrm{ml}$ sterile PBS $(\mathrm{pH} \mathrm{7.2)}$. If the conceptus was present, its morphology was recorded (spherical, tubular, and elongated) and the volume of the uterine flushing recovered was recorded. Photomicrographs of the conceptus were obtained using an inverted microscope fitted with a digital camera. Portions of each conceptus were placed in optimal cutting temperature (OCT) compound (Miles, Oneonta, NY, USA), frozen in liquid nitrogen, and stored at $-80{ }^{\circ} \mathrm{C}$. Another portion of the conceptus was fixed with freshly prepared $4 \%$ (wt/vol) paraformaldehyde in PBS and embedded in paraffin wax. The uterine flush was clarified by centrifugation $(5000 \boldsymbol{g}$ for $15 \mathrm{~min}$ at $4{ }^{\circ} \mathrm{C}$ ), aliquoted, and stored at $-80^{\circ} \mathrm{C}$. The amount of IFNT in the uterine flush was quantified by RIA with a range of detection of $0.1-13 \mathrm{ng} / \mathrm{ml}$ (Antoniazzi et al. 2013). The intraand inter-assay coefficient of variation values were 6.2 and $4.0 \%$ respectively.

\section{RNA isolation and quantitative real-time PCR analysis}

Total cellular RNA was isolated from endometrial samples and conceptuses using Trizol reagent (Invitrogen) according to the manufacturer's instructions. The quantity and quality of total RNA were determined by spectrometry and by denaturing agarose gel electrophoresis respectively. Total RNA samples were digested with RQ1 RNase-Free DNase (Promega) and subsequently cleaned-up using an RNeasy Mini Kit (Qiagen). Total RNA (2100 ng) was reverse transcribed using SuperScript First-Strand Synthesis System for RT-PCR (Invitrogen) following the manufacturer's instructions. Control reactions in the absence of reverse transcriptase were prepared for each sample to detect genomic DNA contamination. The resulting cDNA was stored at $-20^{\circ} \mathrm{C}$ for further analyses.

Quantitative PCR (qPCR) was performed using the ABI prism 7900HT system (Applied Biosystems) with Power SYBR Green PCR Master Mix (Applied Biosystems) as specified by the manufacturer. Specific oligonucleotide primers were designed and analyzed using Primer Express Software for Real Time PCR v3.0 (Applied Biosystems). The primers were blasted using available databases to ensure specificity of each gene in this study and amplicons were verified by sequencing. Forward and reverse primer sequences for all genes analyzed in endometrial samples and conceptuses are listed in Tables 1 and 2 respectively. Primer specificity and efficiency $(-3.22>$ slope $>-3.44$ ) were confirmed using a test amplification run. Each individual sample was run in triplicate using the following conditions: $50{ }^{\circ} \mathrm{C}$ for $2 \mathrm{~min}, 95^{\circ} \mathrm{C}$ for $10 \mathrm{~min}$, and then $95^{\circ} \mathrm{C}$ for $15 \mathrm{~s}$ and $60^{\circ} \mathrm{C}$ for $1 \mathrm{~min}$ for 40 cycles. A dissociation curve was generated to determine amplification of a single product. The threshold line was set at the linear region of the plots above the baseline noise, and threshold cycle $\left(C_{t}\right)$ values were determined at the cycle number at which the threshold line crossed the amplification curve. Mean $C_{\mathrm{t}}$ values for each gene were normalized against average $C_{\mathrm{t}}$ values for the reference gene (ovine alpha-tubulin, TUBA). The relative quantification (RQ) of each gene was calculated using the $2 \Delta \Delta C_{\mathrm{t}}$ method.

\section{Immunohistochemical analyses}

Immunoreactive TLR7 and TLR8 proteins were localized in paraffin-embedded samples from uteri of cyclic and pregnant ewes using the rabbit Vectastain ABC Elite kit (Vector Laboratories, Burlingame, CA, USA) following the manufacturer's instructions. Briefly, antigen retrieval was performed using boiling 
Table 1 Primer sequences used for qPCR in the ovine endometrium.

\begin{tabular}{llll}
\hline Genes & Accession numbers & Forward primers & Reverse primers \\
\hline$T L R 1$ & NM_001135060.2 & AGATGCTGAGAGCCTTCAAG & TTAGACAGTTCCAGACTCAC \\
$T L R 2$ & NM_001048231.1 & CAGGTCAAGGCTTTTCACAC & CCAGGCTTCTTCTCTGTCTT \\
$T L R 3$ & NM_001135928.1 & CAAGTGTCACTGAAGTCATTA & CACAGGTACAATCAAATGGAT \\
$T L R 4$ & NM_001135930.1 & GTGGAGACAAACCTAGTATC & CAGGTTGGGAAGGTCAGAAA \\
$T L R 5$ & NM_001135926.1 & GACTGCCTTGACCTTCTCTTAG & TGCGGTTGTGACTGTCCTGATA \\
$T L R 6$ & NM_001135927.1 & GCGTGTGTCTGATATGGTTA & AAACGACATTGAAGGCACTG \\
$T L R 7$ & NM_001135059.1 & CTGTGATGTCACTCTGGATG & TGAGGTTGGTGGCATTGGCA \\
$T L R 8$ & NM_001135929.1 & TCCACATCCCAGACTTTCTA & GTTCTTGTCCTCACTCTCTT \\
$T L R 9$ & NM_001011555.1 & GTTCTCTCGTATCCCTGTCG & TAGTAGCAGTTGCCGTCCAT \\
$T U B A$ & AF251146.1 & GGTCTTCAAGGCTTCTTGGT & CATAATCGACAGAGAGGCGT \\
\hline
\end{tabular}

citrate and endogenous peroxidase activity was blocked by incubating tissue in methanol with $0.3 \%$ hydrogen peroxide for $15 \mathrm{~min}$ at room temperature. Slides were incubated overnight at $4{ }^{\circ} \mathrm{C}$ with the following primary antibodies: rabbit polyclonal antibodies against TLR7 (ab45371, Abcam, Cambridge, MA, USA) and TLR8 (PA1-12830, Thermo Scientific-Pierce antibodies, Rockford, IL, USA) used at final dilutions of 1:250 and 1:700 respectively.

Fluorescence microscopy and paraffin-immunohistochemistry were utilized to determine knockdown or absence of TLR7 and/or TLR8 proteins in conceptus trophectoderm using the same antibodies described earlier. In addition, cryosections of the uterus were observed for presence of red colored lissaminetagged MAOs. DAPI-counting medium was used to visualize the nuclei in the cryosections. In addition, immunoreactive placenta-associated glycoprotein (PAG) was detected using the same immunohistochemical procedures described in the previous section for detection of TLR7 and TLR8 except that antigen retrieval was performed with protease treatment at $37^{\circ} \mathrm{C}$. Positive immunostaining for PAG is unique to BNCs. The antibody to ovine PAG (kindly provided by Jonathan A Green, University of Missouri) was incubated overnight at a final dilution of 1:400 for conceptus tissue. PAG-stained sections were counterstained with hematoxylin before affixing coverslips. In all cases, negative controls were prepared with rabbit $\lg \mathrm{G}$ at the same concentration as the primary antibody and photomicrographs taken using a Zeiss Axioplan2 microscope fitted with an AxioCam HRc camera (Carl Zeiss, Thornwood, $\mathrm{NY}$, USA). Total conceptus area (in $\mathrm{mm}^{2}$ ) visible in each slide was measured using Image J1.46r (US National Institutes of Health, Bethesda, MD, USA). Those results were then used along with determinations of PAG-positive BNCs in each conceptus to quantify the number of BNCs per conceptus area.

\section{Statistical analysis}

Data were subjected to least-squares ANOVA using Mixed and General Linear Model procedures of the Statistical Analysis System (SAS Institute, Cary, NC, USA). Data obtained from ovine uterine endometria were analyzed for main effects of day and status (cyclic or pregnant), and Day $\times$ Status interaction. Data obtained from conceptuses on Days 13, 14, 15, and 16 of pregnancy and from conceptuses following MAO treatments were assessed for effects of treatment. Effects of morpholino treatments on concentrations of IFNT in uterine flushings were analyzed using ANOVA and orthogonal contrasts to determine differences among treatments (MAO-Control vs MAO-TLR7, vs MAO-TLR8, and vs MAO-TLRT/TLR8). The number of BNCs was quantified by determining numbers of PAG-positive BNCs per unit $\left(\mathrm{mm}^{2}\right)$ of conceptus area in each MAO treatment group. $P \leq 0.05$ was considered statistically significant. Data are expressed as least-squares means with overall S.E.M.

\section{Results}

\section{Expression of TLRs in the endometrium during the estrous cycle and pregnancy}

Expression of TLR1-TLR9 mRNAs was assessed in uterine endometria from cyclic and pregnant ewes by qPCR, and the relative abundance of each TLR was compared (Fig. 1). The pattern of expression of $T L R 2, T L R 7, T L R 8$, and TLR9mRNAs was affected by the day after the onset of estrus and pregnancy status (Day $\times$ Status, $P<0.01$ ). The abundance of these TLR (TLR2, TLR7, TLR8, and TLR9) mRNAs increased from Day 10 to Day 12 of the estrous cycle, and then declined from Day 12 to Day 16; however, expression was maintained between Days 10 and 16 in endometria of pregnant ewes.

With the exception of $T L R 4$, the abundance of the other TLRs differed in response to the day of the estrous cycle or the day of gestation (Day; $P<0.01$ ). During the estrous cycle, expression increased starting from Day 10 and attained maximum levels on Day 12 for TLR1, TLR3, and TLR6, or Day 14 for TLR5. Then, their expression declined on Day 16. In pregnant ewes, relative levels of these TLRs between Days 10 and 14 were similar to that

Table 2 Primer sequences used for qPCR in the conceptus.

\begin{tabular}{llll}
\hline Genes & Accession numbers & Forward primers & Reverse primers \\
\hline$T L R 7$ & NM_001135059.1 & CTGTGATGTCACTCTGGATG & TGAGGTTGGTGGCATTGGCA \\
$T L R 8$ & NM_001135929.1 & TGTGTTTAGAGGAAAGGGATTGG & TCTGCATGAGGTTGTCGATGA \\
enJSRV-Env & AF105220.1 & GGATCTGGACCCCTCGACAT & TGTCTATGCCTATGCCAATGCT \\
$T U B A$ & AF251146.1 & GGTCTTCAAGGCTTCTTGGT & CATAATCGACAGAGAGGCGT \\
\hline
\end{tabular}




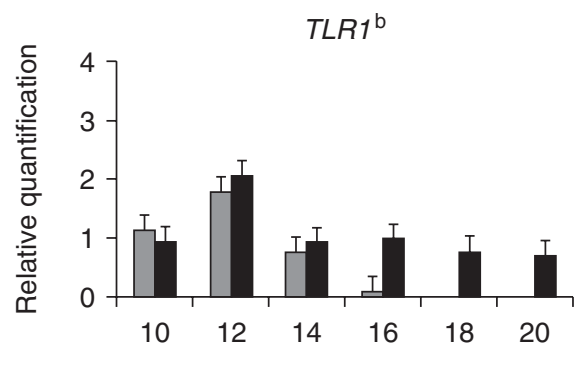

Day of cycle/pregnancy

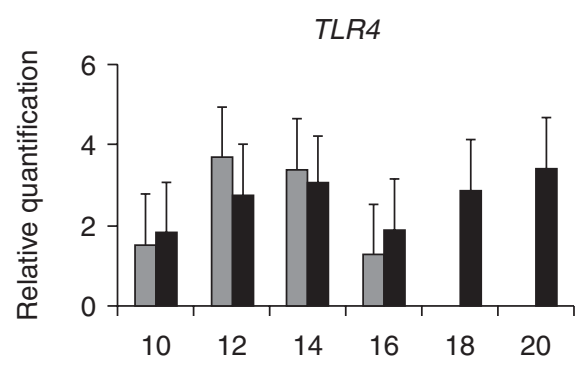

Day of cycle/pregnancy

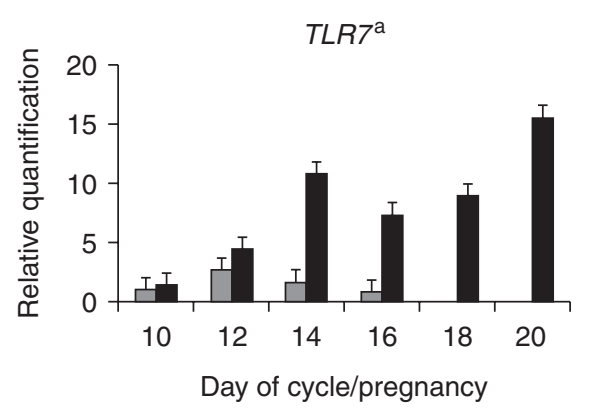

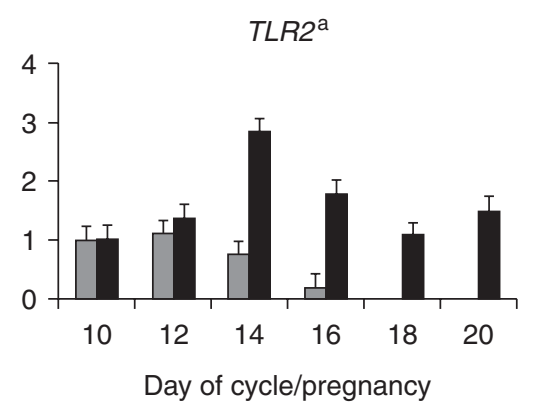
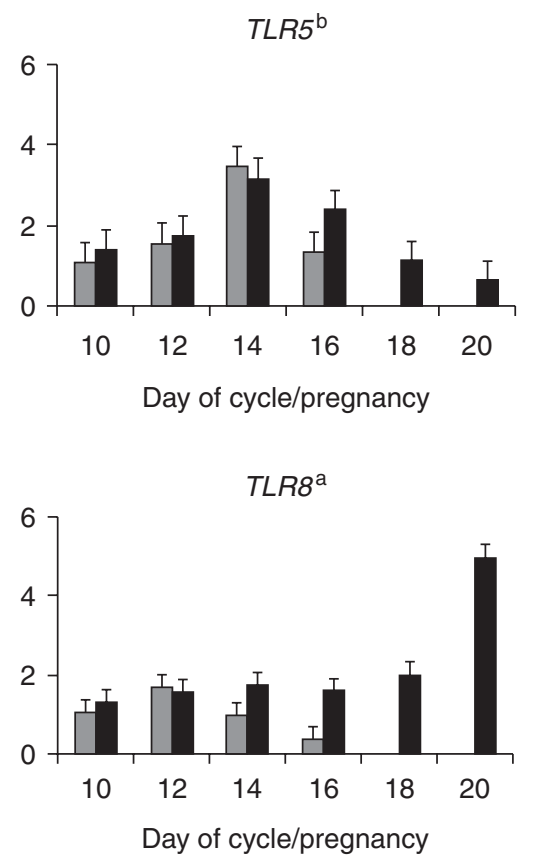
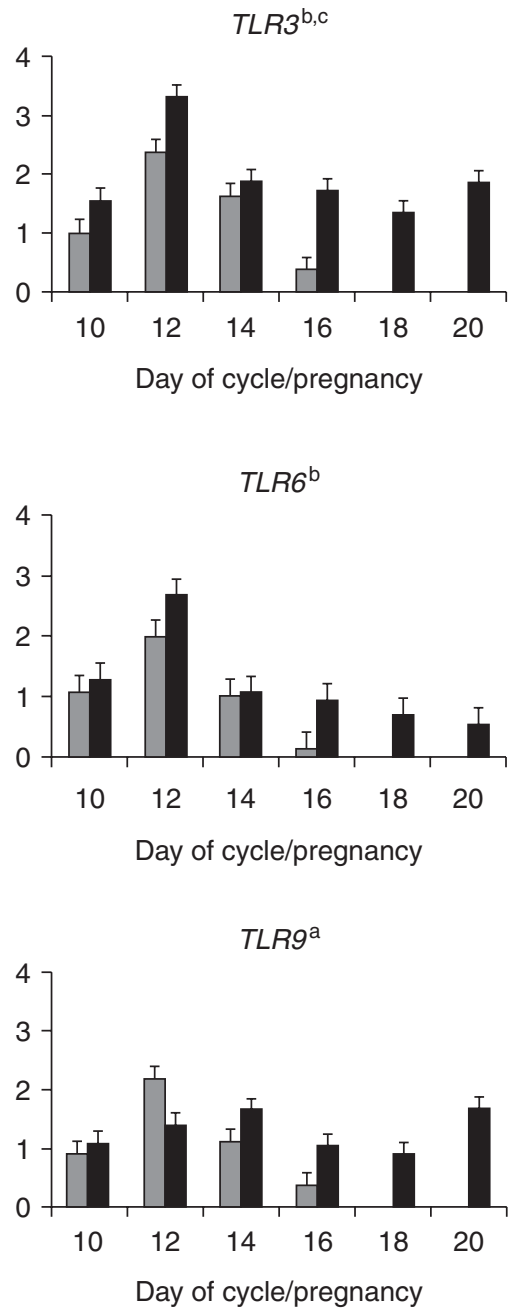

Figure 1 Relative abundance of mRNAs for TLR1-TLR9 in ovine uterine endometria during the estrous cycle and early pregnancy. Data are expressed as abundance of each $T L R$ relative to TUBA. Differences $(P \leq 0.05)$ are denoted with superscripts as follows: ${ }^{a}$ Day $\times$ Pregnancy Status interaction, ${ }^{\mathrm{b}}$ Day effect and ${ }^{\mathrm{C}}$ Pregnancy Status effect.

for cyclic ewes. Then, between Days 16 and 20, expression did not change for TLR1, TLR2, TLR3, or TLR6, but decreased for TLR5, and increased for TLR7 and TLR9.

Expression of TLR2, TLR3, TLR7, and TLR8 was affected by pregnancy status $(P<0.01)$, as their expression was more abundant in endometria of pregnant ewes than in that of cyclic ewes. Although there were significant increases in expression of mRNAs for $T L R 7$ and $T L R 8$ in endometria from pregnant ewes, expression of those TLR mRNAs in ovine conceptuses was not significantly different between Days 13 and 16 of pregnancy (Fig. 2).

\section{Localization of TLR7 and TLR8 proteins in the uterus and trophectoderm}

As shown in Fig. 3, TLR7 and TLR8 proteins were detected in all cells of uteri from cyclic and pregnant ewes, particularly in the uterine luminal (LE) and superficial glandular (sGE) epithelia, and stratum compactum stroma $(\mathrm{S})$.

TLR7 protein was abundant in the uterine LE and stratum compactum stroma on Day 10 of the cycle, but there was stronger expression in the stroma and SGE of uteri from pregnant ewes. Abundance of TLR7 protein increased in uterine LE and SGE as days of the estrous cycle and gestation advanced. In cyclic ewes, TLR7 protein was most abundant in uterine LE and sGE on Day 14 , and then decreased to barely detectable amounts on Day 16. In uteri of pregnant ewes, TLR7 expression was similar on Days 12 and 14, before increasing slightly in uterine LE and sGE on Day 16 of gestation. TLR7 protein was equally abundant in uterine sGE on Days 16, 18, and 20 of pregnancy. At this stage, expression of TLR7 decreased in the uterine LE proximal to the conceptus, but it was strong in the trophectoderm of conceptuses on Days 18 and 20 of pregnancy. 

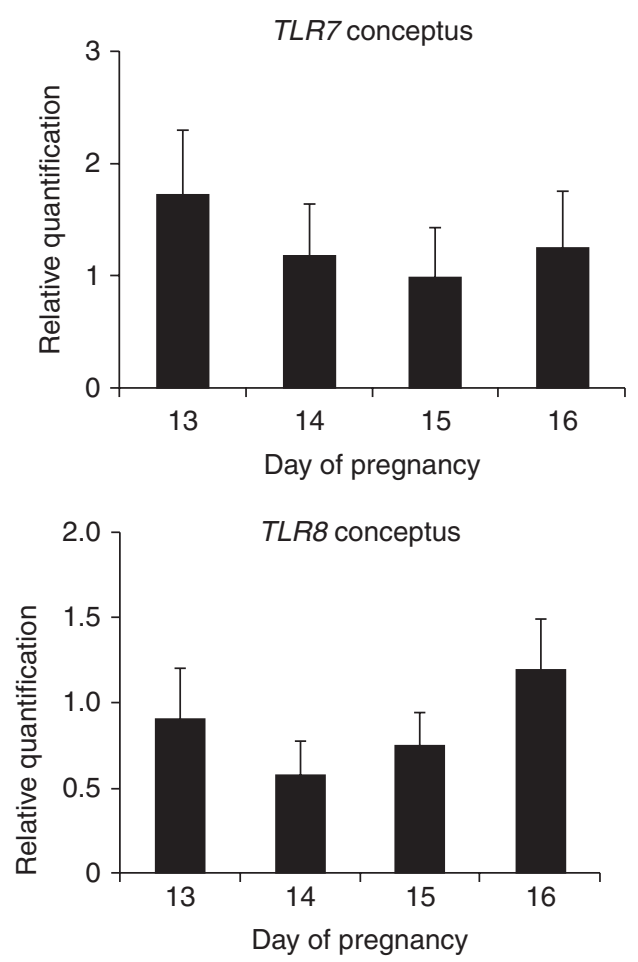

Figure 2 Abundance of $\mathrm{mRNAs}$ for $T L R 7$ and TLR8 in ovine conceptuses during early pregnancy. Data are expressed as abundance of $T L R 7$ and $T L R 8$ relative to TUBA.

Expression of TLR8 protein was detected in uterine LE and stromal cells throughout the estrous cycle. For sGE, the abundance was low on Day 10 and increased from Day 12 to Day 16. In endometria from pregnant ewes, TLR8 protein was similar in abundance in uterine LE, sGE, and stroma on Days 10 and 12. Expression of TLR8 decreased slightly on Day 14 before increasing on Day 16 , and remaining at that level of abundance on Days 18 and 20. TLR8 protein was also detected in conceptus trophectoderm, with the strongest expression in BNCs. In contrast to TLR7 protein, immunoreactive TLR8 protein was abundant in uterine LE independent of proximity to the conceptus.

\section{Knockdown of TLR7 and TLR8 proteins alters conceptus development from Day 8 to Day 16 of pregnancy}

Although treatment with morpholinos did not affect the number of pregnant ewes in each treatment group from which conceptuses were recovered, there were major differences in morphology and degree of development of the conceptuses recovered from ewes that received MAO-TLR7, MAO-TLR8, and MAO-TLR7/TLR8 compared with MAO-Control ewes (Table 3 and Fig. 4). Although most of the conceptuses elongated, MAO$T L R 7$ conceptuses were smaller than the fully elongated and filamentous conceptuses recovered from MAOControl ewes. Conceptuses from MAO-TLR8-treated ewes were more variable in size, but generally smaller when compared with conceptuses from MAO-Control ewes. Conceptuses from ewes treated with MAO-TLR7/ TLR8 were much smaller and more fragile, and they failed to elongate to a filamentous form.

To quantify the effect of the morpholino treatment on function of conceptus trophectoderm, concentrations of IFNT in uterine flushings were determined. Consistent with the abnormal morphology and retarded development, concentrations of IFNT in uterine flushings were

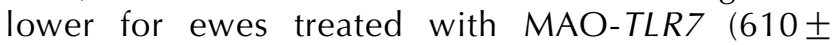
$185 \mathrm{ng} / \mathrm{ml} ; \quad P<0.048), \quad M A O-T L R 8(577 \pm 119 \mathrm{ng} / \mathrm{ml}$; $P<0.049)$, and MAO-TLR7/TLR8 (280 $\pm 133 \mathrm{ng} / \mathrm{ml}$; $P<0.001)$ when compared with the MAO-Control $(1060 \pm 210 \mathrm{ng} / \mathrm{ml})$.

Histological analyses revealed a significant reduction in TLR7 and TLR8 protein expression in conceptuses receiving MAO-TLR7, MAO-TLR8, and MAO$T L R 7 / T L R 8$, which confirmed the efficiency of morpholino knockdown of translation of the respective mRNAs (Fig. 5A, B, and C). The average number of PAG-positive BNCs (Fig. 6) was less $(P<0.05)$ in MAO$T L R 7\left(30.0 \pm 19.0 \mathrm{BNCs} / \mathrm{mm}^{2}\right)$ and MAO-TLRT/TLR8

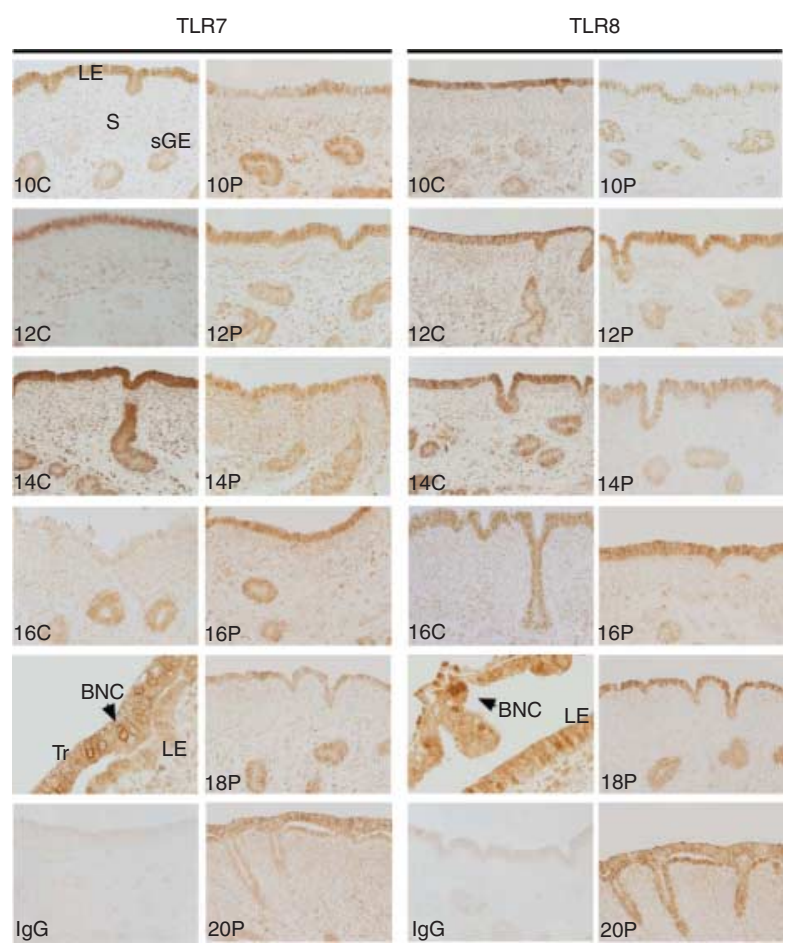

Figure $3 \mathrm{Immunohistochemical} \mathrm{localization} \mathrm{of} \mathrm{TLR7} \mathrm{and} \mathrm{TLR8} \mathrm{proteins}$ in uteri of ewes on Days 10,12,14, and 16 of the estrous cycle and Days 10, 12, 14, 16, 18, and 20 of pregnancy. Sections were not counterstained. LE, luminal epithelium; sGE, superficial glandular epithelium; S, stroma; Tr, trophectoderm; BNCs, binucleate cells. All photographs were taken from uterine cross-sections at $20 \times$ magnification using the same width of field, with the exception of images illustrating TLR7 and TLR8 staining in BNCs, which were taken at $63 \times$ magnification. 
Table 3 Effect of morpholino antisense oligonucleotide knockdown of translation of TLR7, TLR8 and TLR7/TLR8 mRNAs on pregnancy and conceptus development.

\begin{tabular}{lclcc}
\hline Morpholino & Pregnancy rate & Conceptus development & IFNT $(\mathrm{ng} / \mathrm{ml}$ uterine flush) & ${\text { BNCs } / \mathrm{mm}^{2}}^{2}$ \\
MAO-Control & $85.7 \%(6 / 7)$ & Robust, elongated & $1060 \pm 210$ & $90.143 \pm 33.16$ \\
MAO-TLR7 & $75 \%(6 / 8)$ & Thin, fragile, small, some elongated & $610 \pm 185^{*}$ & $30.018 \pm 19.03^{*}$ \\
MAO-TLR8 & $83.3 \%(5 / 6)$ & Small, shredded, fragile. Some elongated & $577 \pm 119^{*}$ & $79.486 \pm 60.01$ \\
MAO-TLR7/TLR8 & $71.4 \%(5 / 7)$ & Small, fragile, fragmented, shredded & $280 \pm 133^{*}$ & $12.225 \pm 5.46^{* *}$ \\
\hline
\end{tabular}

$* P<0.05 ; * * P<0.01$.

conceptuses $\left(12.2 \pm 5.5 \mathrm{BNCs} / \mathrm{mm}^{2} ; P<0.01\right)$ when compared with MAO-Control $\left(90.1 \pm 33.2 \mathrm{BNCs} / \mathrm{mm}^{2}\right)$ conceptuses. PAG-positive cells were scarce or absent in $M A O-T L R 7 / T L R 8$ conceptuses. Owing to a high degree of variability in the number of BNCs among MAO-TLR8 conceptuses $\left(79.5 \pm 60.0 \mathrm{BNCs} / \mathrm{mm}^{2}\right)$, numbers of BNCs were not significantly different from MAO-Control conceptuses.

\section{$T L R 7$ and TLR8 regulate abundance of enJSRV-Env in the conceptus}

Expression of mRNA coding for the envelope protein of the ovine endogenous beta retroviruses (enJSRV-Env) was assessed in conceptuses recovered on different days of pregnancy and from morpholino-treated ewes (Fig. 7). During pregnancy, expression of enJSRV-Env was highest on Day 13 and declined progressively to Day $16(P=0.01)$. Abundance of enJSRV-Env in MAOconceptuses was different among treatment groups. Expression of enJSRV-Env in MAO-TLR7 conceptuses was greater when compared with MAO-TLR8 $(P=0.05)$ and MAO-Control conceptuses $(P=0.01)$, but was similar $(P=0.09)$ to the expression of enJSRV-Env in MAO-TLR7/TLR8 conceptuses.

\section{Discussion}

Results of this study provide initial insight into the expression and potential functions of TLRs in the ovine uterus and conceptus, as well as evidence for involvement of TLR7 and TLR8 in development and differentiated functions of the trophectoderm during the peri-implantation period of pregnancy in ewes.

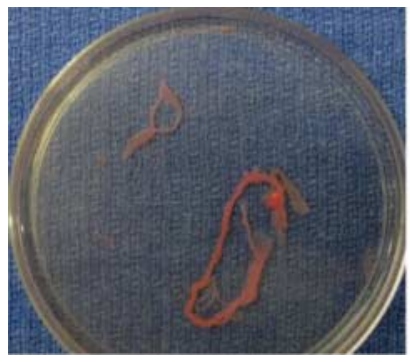

MAO-Control

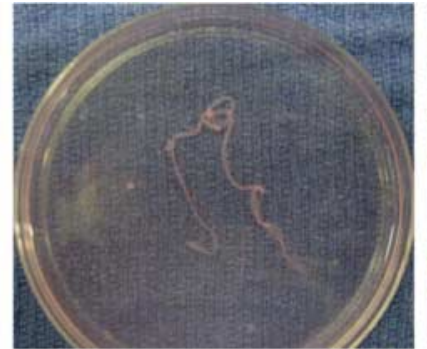

MAO-TLR7

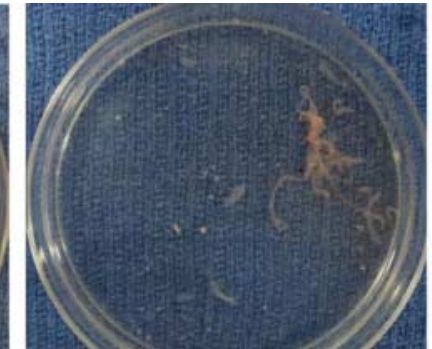

MAO-TLR8

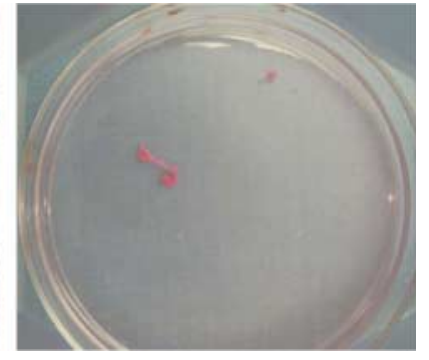

MAO-TLR7/TLR8

Figure 4 Morphological comparison of MAO-treated conceptuses. Representative images demonstrating differences in gross morphology of MAO-Control, MAO-TLR7, MAO-TLR8, and MAO-TLRT/TLR8 conceptuses upon recovery on Day 16 of pregnancy. 

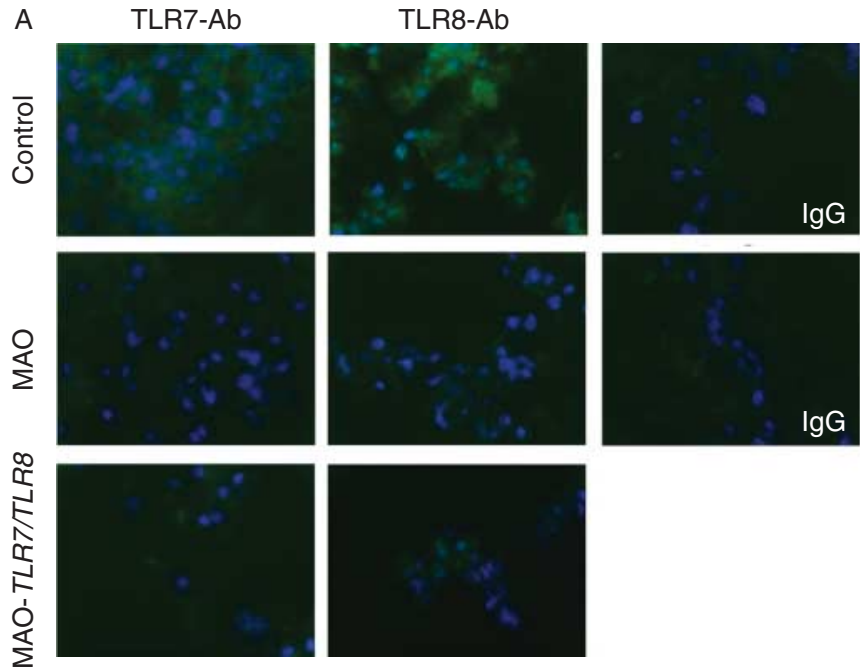

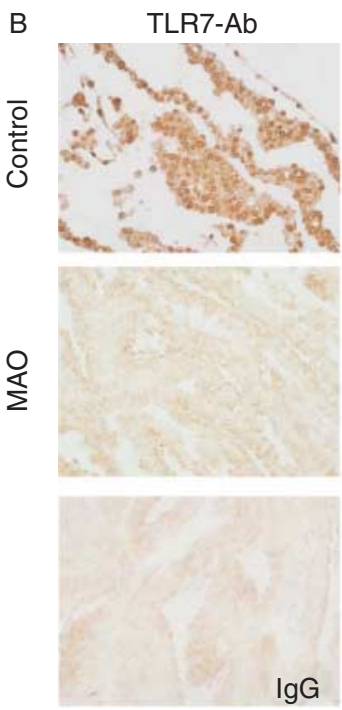

TLR8-Ab

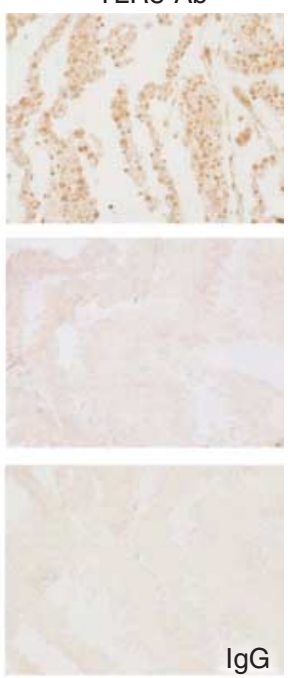

C
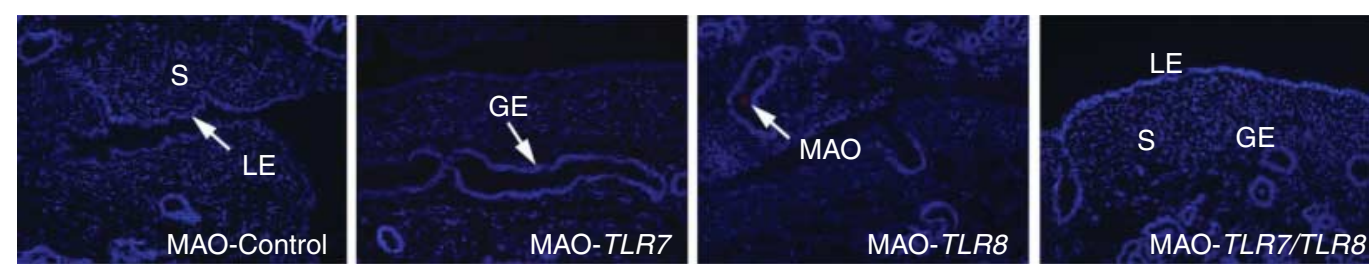

Figure 5 (A, B, and C) Efficiency of morpholino delivery to block translation of TLR7 and TLR8 proteins in the conceptus trophectoderm. (A and B) Immunohistochemical localization of TLR7 and TLR8 in conceptuses recovered from morpholino-treated ewes by (A) fluorescence microscopy and (B) standard paraffin immunohistochemistry. Images demonstrate an efficient morpholino delivery that blocked translation of TLR7 and TLR8 proteins in MAO-TLR7, MAO-TLR8, and MAO-TLR7/TLR8 conceptuses compared with MAO-Controls. Sections with standard paraffin immunohistochemistry were not counterstained. Representative pictures of immunofluorescence and standard immunohistochemical analysis were taken at magnifications of $40 \times$ and $10 \times$, respectively, using the same width of field. Ab, antibody used for the analysis. (C) Immunofluorescence analysis demonstrated absence of lissamine-tagged MAO uptake by the uterine epithelial cells. Image width of field $=900 \mu \mathrm{m}$. LE, luminal epithelium; sGE, superficial glandular epithelium; S, stroma.

status, which supports results obtained from previous studies (Jorgenson et al. 2005, Aflatoonian et al. 2007, Hirata et al. 2007).

The uterine epithelia constitute a primary barrier against pathogens, while also ensuring tolerance to the implanting conceptus and producing nutrients and adhesion molecules indispensable for pregnancy (Burghardt et al. 2002, Spencer \& Bazer 2004, Gray et al. 2006). Progesterone is claimed to suppress or modify the immune system during pregnancy to avoid rejection of the semi-allogeneic conceptus (Hansen 1998); however, expression of the progesterone receptor declines after Day 12 in all uterine epithelia of ewes. Thus, direct actions of progesterone are limited after Day 12 of pregnancy to stromal cells and myometrium as they continue to express the progesterone receptor throughout gestation (Spencer et al. 2004, Bazer et al. 2008). In this study, expression of both TLR7 and TLR8 increased in uterine LE and SGE following down-regulation of the progesterone receptor (Spencer \& Bazer 1995). The selective loss of a direct influence via progesterone may allow expression of TLRs to be maintained in the epithelia to ensure protection against pathogens and to influence conceptus development.

In ewes, maternal recognition of pregnancy occurs between Days 12 and 14 of gestation when an appropriately elongated and filamentous conceptus signals its presence by secreting IFNT. This cytokine acts in a paracrine manner on uterine epithelia to abrogate development of the luteolytic mechanism (Spencer \& Bazer 2004) and to induce expression of genes critical to establishment and maintenance of pregnancy (Bazer et al. 2012). The morpholino-treated conceptuses in this study did elongate; however, they secreted less IFNT due to being developmentally retarded and morphologically disorganized compared to control conceptuses. Those results indicate essential roles played by TLR7 and TLR8 in the trophectoderm that influence conceptus development directly or indirectly, and therefore, IFNT production.

This study also revealed that MAO-TLR7 and MAO$T L R 7 / T L R 8$ conceptuses had significantly fewer BNCs in the trophectoderm, which impairs their ability to fuse with the uterine LE and undergo implantation. Moreover, BNCs 

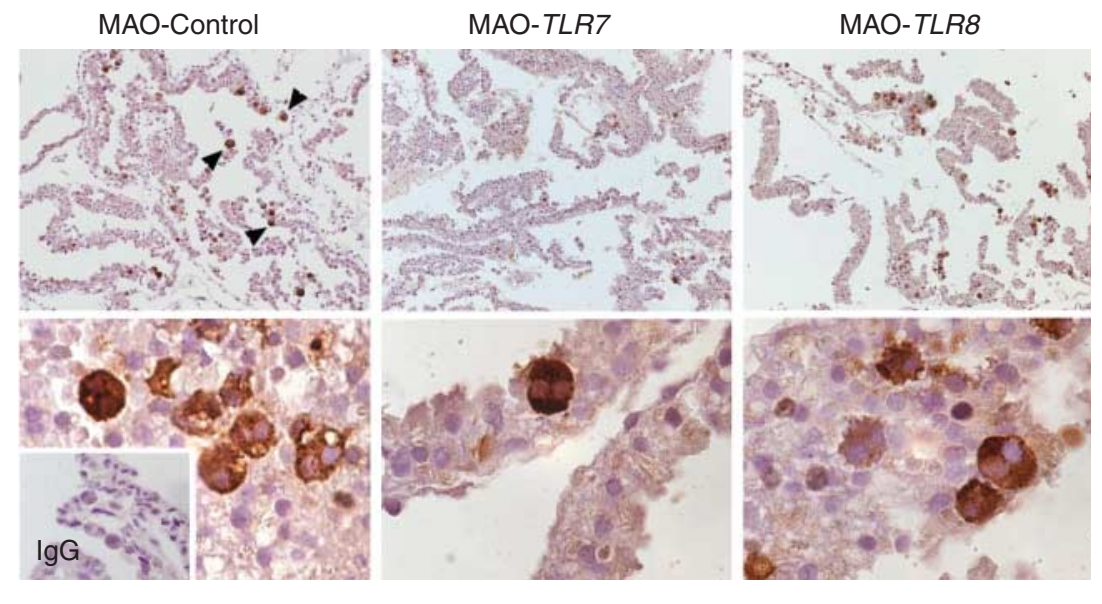

Figure 6 Immunohistochemical localization of PAG proteins in morpholino-treated conceptuses. MAOTLR7 and MAO-TLRT/TLR8 conceptuses had significantly fewer PAG-positive BNCs than MAOControl conceptuses. This effect was especially evident when blocking translation of TLR7 mRNA. Variability was very high among conceptuses from the MAO-TLR8 treatment group. Images illustrating specific staining in BNCs were taken at a magnification of $63 \times$. secrete placental lactogen (CSH1) and progesterone, which stimulate endometrial gland morphogenesis and differentiated functions during pregnancy in support of conceptus development. Interestingly, the ovine endogenous beta retroviruses (enJSRVs) included in sheep genome (Palmarini et al. 2001) are responsible for formation of BNCs (Dunlap et al. 2005, 2006a,b). During pregnancy, viral particles shed into the uterine lumen transfect conceptus trophectoderm (Black et al. 2010) as early as Day 12 (Dunlap et al. 2005) and influence development, IFNT production, and BNC formation (Dunlap et al. 2006a). Ovine enJSRV Envelope protein is a member of the syncytin family of retroviral proteins with high fusogenic activity responsible for inducing formation of the syncytiotrophoblasts in placenta of various species (Mi et al. 2000, Cornelis et al. 2013). In the ovine conceptus, mononuclear trophectoderm cells express abundant enJSRV-Env protein by Day 16 of pregnancy (Dunlap et al. 2006a). By Day 20, its expression appears to be limited to BNCs and syncytia (Dunlap et al. 2005), suggesting that this protein induces cell fusion that leads to BNC formation. Blockage of enJSRV-Env mRNA translation results in retarded development, decreased secretion of IFNT, and few or no BNCs in ovine conceptuses (Dunlap et al. 2006a). Thus, enJSRVEnv could interact with TLR7 to influence conceptus development, IFNT production, and BNC formation by ovine trophectoderm cells.

This study revealed that expression of enJSRV-Env mRNA by conceptus trophectoderm decreases between Days 13 and 16 of a normal pregnancy. This decline of enJSRV mRNA could result from active processing through recruitment and activation of antiviral ISGs such as $\mathrm{Mx}$ or $2^{\prime}, 5^{\prime}$-oligoadenylate synthetase (OAS), which are known to be induced by IFNT (Johnson et al. 2001, 2002). On the other hand, enJSRV-Env mRNA may accumulate under the influence of a regulatory feedback controlled by secretions from BNCs, which would account for the decline in enJSRV-Env mRNA around Day 16 as numbers of BNC increase. Regardless, treatment with MAO-TLR7 affects enJSRV mRNA expression, which opens the possibility for TLR7 involvement in recognition of maternal viral particles (Black et al. 2010) or regulation of enJSRV abundance during the period when expression of IFNT increases rapidly. Till date, this role had been assigned to the proposed cellular receptor, hyaluronidase 2 (HYAL2),
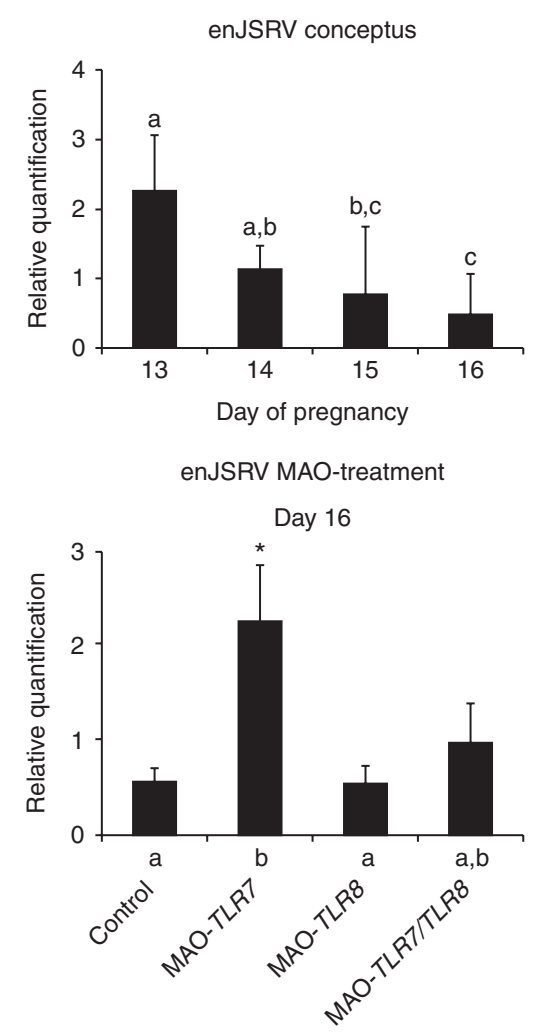

Figure 7 Abundance of mRNA coding for the envelope protein of enJSRV (enJSRV-Env) in ovine conceptuses during early pregnancy (top panel) and in MAO-treated conceptuses recovered on Day 16 (bottom panel). Data are expressed as levels of enJSRV-Env relative to TUBA. Different superscripts $\left({ }^{\mathrm{a}, \mathrm{b}, \mathrm{c}}\right)$ denote significant effects of days. The asterisk $(*)$ indicates a significant treatment effect of MAO-TLR7 $(P \leq 0.05)$. 
although it is not expressed by the conceptus until Day 16 when secretion of IFNT is actually decreasing (Dunlap et al. 2005). Thus, future experiments are necessary to clarify the mechanism(s) by which TLRs, particularly TLR7, are involved in key events during the peri-implantation period of pregnancy.

In summary, results of this study document patterns of expression of TLR1-TLR9 in ovine uterine endometria and conceptuses during the estrous cycle and the periimplantation period of pregnancy, with significant differences in temporal and cell-specific expression of endometrial TLR7 and TLR8. Mechanistically, our in vivo loss-of-function experiments provide evidence for essential roles of TLR7 and TLR8 in conceptus development, pregnancy recognition signaling by IFNT, and formation of BNCs. These results provide strong evidence in support of our hypothesis that members of the TLR family are critical to the establishment and maintenance of pregnancy in ewes.

\section{Declaration of interest}

The authors declare that there is no conflict of interest that could be perceived as prejudicing the impartiality of the research reported.

\section{Funding}

This research did not receive any specific grant from any funding agency in the public, commercial or not-for-profit sector; however, Dr I Ruiz-González was supported by a Fellowship for Graduate Courses in Universities and Colleges 2012 from the Caja Madrid Foundation (Spain).

\section{Acknowledgements}

The authors thank all members of the Laboratory for Uterine Biology and Pregnancy, and Kendrick LeBlanc at Texas A\&M University for management of the sheep used in this study. They are thankful to Dr Jonathan A Green for supplying the polyclonal PAG antibody, Dr Thomas ' $\mathrm{Tod}^{\prime} \mathrm{R}$ Hansen for conducting the RIA for IFNT, and Dr Robert C Burghardt for his assistance with photomicrograph processing.

\section{References}

Abrahams VM, Bole-Aldo P, Kim YM, Straszewski-Chavez SL, Chaiworapongsa T, Romero R \& Mor G 2004 Divergent trophoblast responses to bacterial products mediated by TLRs. Journal of Immunology 173 4286-4296. (doi:10.4049/jimmunol.173.7.4286)

Abrahams VM, Visintin I, Aldo PB, Guller S, Romero R \& Mor G 2005 A role for TLRs in the regulation of immune cell migration by first trimester trophoblast cells. Journal of Immunology 175 8096-8104. (doi:10.4049/ jimmunol.175.12.8096)

Aflatoonian R, Tuckerman E, Elliott SL, Bruce C, Aflatoonian A, Li TC \& Fazeli A 2007 Menstrual cycle-dependent changes of Toll-like receptors in endometrium. Human Reproduction 22 586-593. (doi:10.1093/ humrep/del388)
Akira S \& Hemmi H 2003 Recognition of pathogen-associated molecular patterns by TLR family. Immunology Letters 85 85-95. (doi:10.1016/ S0165-2478(02)00228-6)

Akira S, Takeda K \& Kaisho T 2001 Toll-like receptors: critical proteins linking innate and acquired immunity. Nature Immunology 2 675-680. (doi:10.1038/90609)

Antoniazzi AQ, Webb BT, Romero JJ, Ashley RL, Smirnova NP, Henkes LE, Bott RC, Oliveira JF, Niswender GD, Bazer FW et al. 2013 Endocrine delivery of interferon tau protects the corpus luteum from prostaglandin $\mathrm{F}_{2 \alpha}$-induced luteolysis in ewes. Biology of Reproduction 88 144, 1-12. (doi:10.1095/biolreprod.112.105684)

Ashkar AA \& Croy BA 2001 Functions of uterine natural killer cells are mediated by interferon $\gamma$ production during murine pregnancy. Seminars in Immunology 13 235-241. (doi:10.1006/smim.2000.0319)

Bazer FW, Burghardt RC, Johnson GA, Spencer TE \& Wu G 2008 Interferons and progesterone for establishment and maintenance of pregnancy: interactions among novel cell signaling pathways. Reproductive Biology 8 179-211. (doi:10.1016/S1642-431X(12)60012-6)

Bazer FW, Song G, Kim J, Dunlap KA, Satterfield MC, Johnson GA, Burghardt RC \& Wu GY 2012 Uterine biology in pigs and sheep. Journal of Animal Science and Biotechnology 3 23, 1-21. (doi:10.1186/ 2049-1891-3-23)

Black SG, Arnaud F, Burghardt RC, Satterfield MC, Fleming JA, Long CR, Hanna C, Murphy L, Biek R, Palmarini M et al. 2010 Viral particles of endogenous betaretroviruses are released in the sheep uterus and infect the conceptus trophectoderm in a transspecies embryo transfer model. Journal of Virology 84 9078-9085. (doi:10.1128/JVI. 00950-10)

Burghardt RC, Johnson GA, Jaeger LA, Ka H, Garlow JE, Spencer TE \& Bazer FW 2002 Integrins and extracellular matrix proteins at the maternal-fetal interface in domestic animals. Cells, Tissues, Organs 172 202-217. (doi:10.1159/000066969)

Chang JS, Russell GC, Jann O, Glass EJ, Werling D \& Haig DM 2009 Molecular cloning and characterization of Toll-like receptors 1-10 in sheep. Veterinary Immunology and Immunopathology 127 94-105. (doi:10.1016/j.vetimm.2008.09.026)

Cornelis G, Heidmann O, Degrelle SA, Vernochet C, Lavialle C, Letzelter C, Bernard-Stoecklin S, Hassanin A, Mulot B, Guillomot M et al. 2013 Captured retroviral envelope syncytin gene associated with the unique placental structure of higher ruminants. PNAS 110 E828-E837. (doi:10.1073/pnas.1215787110)

Davies D, Meade KG, Herath S, Eckersall PD, Gonzalez D, White JO, Conlan RS, O'Farrelly C \& Sheldon IM 2008 Toll-like receptor and antimicrobial peptide expression in the bovine endometrium. Reproductive Biology and Endocrinology 6 53. (doi:10.1186/14777827-6-53)

Dorniak P, Bazer FW \& Spencer TE 2011 Prostaglandins regulate conceptus elongation and mediate effects of interferon tau on the ovine uterine endometrium. Biology of Reproduction 84 1119-1127. (doi:10.1095/ biolreprod.110.089979)

Dunlap KA, Palmarini M, Adelson DL \& Spencer TE 2005 Sheep endogenous betaretroviruses (enJSRVs) and the hyaluronidase 2 (HYAL2) receptor in the ovine uterus and conceptus. Biology of Reproduction 73 271-279. (doi:10.1095/biolreprod.105.039776)

Dunlap KA, Palmarini M, Varela M, Burghardt RC, Hayashi K, Farmer JL \& Spencer TE 2006a Endogenous retroviruses regulate periimplantation placental growth and differentiation. PNAS 103 14390-14395. (doi:10. 1073/pnas.0603836103)

Dunlap KA, Palmarini M \& Spencer TE 2006b Ovine endogenous betaretroviruses (enJSRVs) and placental morphogenesis. Placenta 27 S135-S140. (doi:10.1016/j.placenta.2005.12.009)

Erlebacher A 2013 Immunology of the maternal-fetal interface. Annual Review of Immunology 31 387-411. (doi:10.1146/annurev-immunol032712-100003)

Fleming JA, Song G, Choi Y, Spencer TE \& Bazer FW 2009 Interferon regulatory factor 6 (IRF6) is expressed in the ovine uterus and functions as a transcriptional activator. Molecular and Cellular Endocrinology 299 252-260. (doi:10.1016/j.mce.2008.10.025)

Gomez-Lopez N, Guilbert LJ \& Olson DM 2010 Invasion of the leukocytes into the fetal-maternal interface during pregnancy. Journal of Leukocyte Biology 88 625-633. (doi:10.1189/jlb.1209796) 
Granot I, Gnainsky Y \& Dekel N 2012 Endometrial inflammation and effect on implantation improvement and pregnancy outcome. Reproduction 144 661-668. (doi:10.1530/REP-12-0217)

Gray CA, Abbey CA, Beremand PD, Choi Y, Farmer JL, Adelson DL, Thomas TL, Bazer FW \& Spencer TE 2006 Identification of endometrial genes regulated by early pregnancy, progesterone, and interferon tau in the ovine uterus. Biology of Reproduction 74 383-394. (doi:10.1095/ biolreprod.105.046656)

Greenwood JD, Minhas K, di Santo JP, Makita M, Kiso Y \& Croy BA 2000 Ultrastructural studies of implantation sites from mice deficient in uterine natural killer cells. Placenta 21 693-702. (doi:10.1053/plac. 2000.0556)

Guerin LR, Prins JR \& Robertson SA 2009 Regulatory T-cells and immune tolerance in pregnancy: a new target for infertility treatment? Human Reproduction Update 15 517-535. (doi:10.1093/humupd/dmp004)

Hadfield KA, McCracken SA, Ashton AW, Nguyen TG \& Morris JM 2011 Regulated suppression of NF-KB throughout pregnancy maintains a favourable cytokine environment necessary for pregnancy success. Journal of Reproductive Immunology 89 1-9. (doi:10.1016/j.jri.2010. 11.008)

Hansen PJ 1998 Regulation of uterine immune function by progesterone lessons from the sheep. Journal of Reproductive Immunology 40 63-79. (doi:10.1016/S0165-0378(98)00035-7)

Hansen JD, Vojtech LN \& Laing KJ 2011 Sensing disease and danger: a survey of vertebrate PRRs and their origins. Developmental and Comparative Immunology 35 886-897. (doi:10.1016/j.dci.2011.01.008)

Herath S, Fischer DP, Werling D, Williams EJ, Lilly ST, Dobson H, Bryant CE \& Sheldon IM 2006 Expression and function of Toll-like receptor 4 in the endometrial cells of the uterus. Endocrinology 147 562-570. (doi:10.1210/en.2005-1113)

Hess AP, Hamilton AE, Talbi S, Dosiou C, Nyegaard M, Nayak N, Genbecev-Krtolica O, Mavrogianis P, Ferrer K, Kruessel J et al. 2007 Decidual stromal cell response to paracrine signals from the trophoblast: amplification of immune and angiogenic modulators. Biology of Reproduction 76 102-117. (doi:10.1095/biolreprod.106.054791)

Hirata T, Osuga Y, Hamasaki K, Hirota Y, Nose E, Morimoto C, Harada M, Takemura Y, Koga K, Yoshino O et al. 2007 Expression of Toll-like receptors 2, 3, 4, and 9 genes in the human endometrium during the menstrual cycle. Journal of Reproductive Immunology 74 53-60. (doi:10.1016/j.jri.2006.11.004)

Jabbour HN, Sales KJ, Catalano RD \& Norman JE 2009 Inflammatory pathways in female reproductive health and disease. Reproduction 138 903-919. (doi:10.1530/REP-09-0247)

Janeway CA Jr \& Medzhitov R 2002 Innate immune recognition. Annual Review of Immunology 20 197-216. (doi:10.1146/annurev.immunol.20. 083001.084359)

Johnson GA, Stewart MD, Gray CA, Choi Y, Burghardt RC, Yu-Lee LY, Bazer FW \& Spencer TE 2001 Effects of the estrous cycle, pregnancy, and interferon tau on $2^{\prime}, 5^{\prime}$-oligoadenylate synthetase expression in the ovine uterus. Biology of Reproduction 64 1392-1399. (doi:10.1095/biolreprod64.5.1392)

Johnson GA, Joyce MM, Yankey SJ, Hansen TR \& Ott TL 2002 The interferon stimulated genes (ISG) 17 and Mx have different temporal and spatial expression in the ovine uterus suggesting more complex regulation of the Mx gene. Journal of Endocrinology 174 R7-R11. (doi:10.1677/joe.0.174R007)

Jorgenson RL, Young SL, Lesmeister MJ, Lyddon TD \& Misfeldt ML 2005 Human endometrial epithelial cells cyclically express Toll-like receptor 3 (TLR3) and exhibit TLR3-dependent responses to dsRNA. Human Immunology 66 469-482. (doi:10.1016/j.humimm.2004.12.003)

Jungi TW, Farhat K, Burgener IA \& Werling D 2011 Toll-like receptors in domestic animals. Cell and Tissue Research 343 107-120. (doi:10.1007/ s00441-010-1047-8)

Kawai T \& Akira S 2009 The roles of TLRs, RLRs and NLRs in pathogen recognition. International Immunology 21 317-337. (doi:10.1093/ intimm/dxp017)

King AE \& Critchley HO 2010 Oestrogen and progesterone regulation of inflammatory processes in the human endometrium. Journal of Steroid Biochemistry and Molecular Biology 120 116-126. (doi:10.1016/j. jsbmb.2010.01.003)
King AE, Critchley HO \& Kelly RW 2001 The NF-кB pathway in human endometrium and first trimester decidua. Molecular Human Reproduction 7 175-183. (doi:10.1093/molehr/7.2.175)

Koga K \& Mor G 2010 Toll-like receptors at the maternal-fetal interface in normal pregnancy and pregnancy disorders. American Journal of Reproductive Immunology 63 587-600. (doi:10.1111/j.1600-0897. 2010.00848.x)

Kumar H, Kawai T \& Akira S 2009 Toll-like receptors and innate immunity. Biochemical and Biophysical Research Communications 388 621-625. (doi:10.1016/j.bbrc.2009.08.062)

Laskarin G, Kammerer U, Rukavina D, Thomson AW, Fernandez N \& Blois SM 2007 Antigen-presenting cells and materno-fetal tolerance: an emerging role for dendritic cells. American Journal of Reproductive Immunology 58 255-267. (doi:10.1111/j.1600-0897.2007.00511.x)

Leonard S, Murrant C, Tayade C, van den Heuvel M, Watering R \& Croy BA 2006 Mechanisms regulating immune cell contributions to spiral artery modification - facts and hypotheses - a review. Placenta 27 (Suppl A) S40-S46. (doi:10.1016/j.placenta.2005.11.007)

Li X, Jiang S \& Tapping RI 2010 Toll-like receptor signaling in cell proliferation and survival. Cytokine 49 1-9. (doi:10.1016/j.cyto.2009. 08.010)

Mansouri-Attia N, Oliveira LJ, Forde N, Fahey AG, Browne JA, Roche JF, Sandra O, Reinaud P, Lonergan P \& Fair T 2012 Pivotal role for monocytes/macrophages and dendritic cells in maternal immune response to the developing embryo in cattle. Biology of Reproduction 87 123. (doi:10.1095/biolreprod.112.101121)

Maybin JA, Critchley HO \& Jabbour HN 2011 Inflammatory pathways in endometrial disorders. Molecular and Cellular Endocrinology 335 42-51. (doi:10.1016/j.mce.2010.08.006)

Menzies M \& Ingham A 2006 Identification and expression of Toll-like receptors 1-10 in selected bovine and ovine tissues. Veterinary Immunology and Immunopathology 109 23-30. (doi:10.1016/ j.vetimm.2005.06.014)

Mi S, Lee X, Li XP, Veldman GM, Finnerty H, Racie L, LaVallie E, Tang XY, Edouard P, Howes S et al. 2000 Syncytin is a captive retroviral envelope protein involved in human placental morphogenesis. Nature $\mathbf{4 0 3}$ 785-789. (doi:10.1038/35001608)

Nagamatsu T \& Schust DJ 2010 The immunomodulatory roles of macrophages at the maternal-fetal interface. Reproductive Sciences $\mathbf{1 7}$ 209-218. (doi:10.1177/1933719109349962)

Nalubamba KS, Gossner AG, Dalziel RG \& Hopkins J 2007 Differential expression of pattern recognition receptors in sheep tissues and leukocyte subsets. Veterinary Immunology and Immunopathology $\mathbf{1 1 8}$ 252-262. (doi:10.1016/j.vetimm.2007.05.018)

O'Mahony DS, Pham U, lyer R, Hawn TR \& Liles WC 2008 Differential constitutive and cytokine-modulated expression of human Toll-like receptors in primary neutrophils, monocytes, and macrophages. International Journal of Medical Sciences 5 1-8. (doi:10.7150/ijms.5.1)

Ott TL \& Gifford CA 2010 Effects of early conceptus signals on circulating immune cells: lessons from domestic ruminants. American Journal of Reproductive Immunology 64 245-254. (doi:10.1111/j.1600-0897. 2010.00912.x)

Palmarini M, Gray CA, Carpenter K, Fan H, Bazer FW \& Spencer TE 2001 Expression of endogenous betaretroviruses in the ovine uterus: effects of neonatal age, estrous cycle, pregnancy, and progesterone. Journal of Virology 75 11319-11327. (doi:10.1128/JVI.75.23.11319-11327.2001)

Pan H, Zhu L, Deng Y \& Pollard JW 2006 Microarray analysis of uterine epithelial gene expression during the implantation window in the mouse. Endocrinology 147 4904-4916. (doi:10.1210/en.2006-0140)

Paulesu L, Bhattacharjee J, Bechi N, Romagnoli R, Jantra S \& letta F 2010 Proinflammatory cytokines in animal and human gestation. Current Pharmaceutical Design 16 3601-3615. (doi:10.2174/138161210793797933)

Piccinni MP, Scaletti C, Vultaggio A, Maggi E \& Romagnani S 2001 Defective production of LIF, M-CSF and Th2-type cytokines by T cells at fetomaternal interface is associated with pregnancy loss. Journal of Reproductive Immunology 52 35-43. (doi:10.1016/S0165-0378(01)00111-5)

Plaks V, Birnberg T, Berkutzki T, Sela S, BenYashar A, Kalchenko V, Mor G, Keshet E, Dekel N, Neeman M et al. 2008 Uterine DCs are crucial for decidua formation during embryo implantation in mice. Journal of Clinical Investigation 118 3954-3965. (doi:10.1172/JCl36682)

Ross JW, Ashworth MD, Mathew D, Reagan P, Ritchey JW, Hayashi K, Spencer TE, Lucy M \& Geisert RD 2010 Activation of the transcription 
factor, nuclear factor $\mathrm{\kappa}-\mathrm{B}$, during the estrous cycle and early pregnancy in the pig. Reproductive Biology and Endocrinology 8 39. (doi:10.1186/ 1477-7827-8-39)

Segerson EC, Matterson PM \& Gunsett FC 1991 Endometrial T-lymphocyte subset infiltration during the ovine estrous cycle and early pregnancy. Journal of Reproductive Immunology 20 221-236. (doi:10.1016/01650378(91)90048-U)

Spencer TE \& Bazer FW 1995 Temporal and spatial alterations in uterine estrogen receptor and progesterone receptor gene expression during the estrous cycle and early pregnancy in the ewe. Biology of Reproduction 53 1527-1543. (doi:10.1095/biolreprod53.6.1527)

Spencer TE \& Bazer FW 2004 Conceptus signals for establishment and maintenance of pregnancy. Reproductive Biology and Endocrinology 2 49. (doi:10.1186/1477-7827-2-49)

Spencer TE, Ott TL \& Bazer FW 1998 Expression of interferon regulatory factors one and two in the ovine endometrium: effects of pregnancy and ovine interferon tau. Biology of Reproduction 58 1154-1162. (doi:10.1095/biolreprod58.5.1154)

Spencer TE, Bartol FF, Bazer FW, Johnson GA \& Joyce MM 1999 Identification and characterization of glycosylation-dependent cell adhesion molecule 1-like protein expression in the ovine uterus. Biology of Reproduction 60 241-250. (doi:10.1095/biolreprod60. 2.241)

Spencer TE, Johnson GA, Burghardt RC \& Bazer FW 2004 Progesterone and placental hormone actions on the uterus: insights from domestic animals. Biology of Reproduction 71 2-10. (doi:10.1095/biolreprod. 103.024133)
Tirumurugaan KG, Dhanasekaran S, Raj GD, Raja A, Kumanan K \& Ramaswamy V 2010 Differential expression of Toll-like receptor mRNA in selected tissues of goat (Capra hircus). Veterinary Immunology and Immunopathology 133 296-301. (doi:10.1016/j.vetimm. 2009.08.015)

Turner ML, Healey GD \& Sheldon IM 2012 Immunity and inflammation in the uterus. Reproduction in Domestic Animals 47 (Suppl 4) 402-409. (doi:10.1111/j.1439-0531.2012.02104.x)

Wang X, Ying W, Dunlap KA, Lin G, Satterfield MC, Burghardt RC, Wu G \& Bazer FW 2014 Arginine decarboxylase and agmatinase: an alternative pathway for de novo biosynthesis of polyamines for development of mammalian conceptuses. Biology of Reproduction 90 84. (doi:10.1095/ biolreprod.113.114637)

Warning JC, McCracken SA \& Morris JM 2011 A balancing act: mechanisms by which the fetus avoids rejection by the maternal immune system. Reproduction 141 715-724. (doi:10.1530/REP-10-0360)

Young SL, Lyddon TD, Jorgenson RL \& Misfeldt ML 2004 Expression of Tolllike receptors in human endometrial epithelial cells and cell lines. American Journal of Reproductive Immunology 52 67-73. (doi:10.1111/ j.1600-0897.2004.00189.x)

Received 8 October 2014

First decision 7 November 2014

Revised manuscript received 6 January 2015

Accepted 14 January 2015 